\title{
ELECTROCARDIOGRAPHIC CHANGES IN ACUTE POLIOMYELITIS IN CHILDHOOD
}

\author{
BY \\ L. M. ROSE \\ From The Children's Hospital, Birmingham
}

Received October 15, 1951

The early pathological accounts of poliomyelitis were limited to descriptions of the changes in the neuraxis. Wickman (1907) in his classical monograph on the disease alluded to the common occurrence of lymphoid hyperplasia, as did Harbitz and Scheel (1907), and Peabody et al. (1912), but none of these writers mentioned myocardial lesions. Robertson and Chesley (1910) observed swelling of myocardial fibres accompanied by interstitial œdema in 4 of 6 patients dying from poliomyelitis: this appears to be the first mention of myocardial damage in poliomyelitis. In 1918, Abramson described perivascular collections of mononuclear cells in the connective tissue septa between normal muscle bundles. Further brief descriptions of myocardial lesions were given by Cowie et al. (1934) and Clark (1938). Saphir and Wile (1942) noted myocardial changes in 6 of 7 patients dying early in the disease; five of these patients were children between 4 and 14 years old; one was 23, and one 34 . They described foci of infiltration with lymphocytes and polymorphonuclear leucocytes around vessels in the myocardium and, in some cases, monocytes and adventitial cells were also present; the muscle fibres showed only minimal degenerative changes.

Further reports on the myocardial lesions have been made by Peale and Lucchesi (1943), Dublin and Larson (1943), Saphir (1945), Gefter et al. (1947), Dolgopol and Cragan (1948), Ludden and Edwards (1949), and Spain et al. (1950). Detailed reports on single cases have been given by Hassin (1943), Boucek et al. (1949), and Baskin et al. (1950). It is of interest that similar cardiac findings have been described in infective polyneuritis by Sabin and Aring (1941).

The incidence of myocardial damage detected in poliomyelitis varies widely. This may be due to the thoroughness of examination for if the whole heart is examined microscopically more lesions will be revealed than when only a few sections are examined. It is also possible that the incidence of cardiac damage varies in different epidemics (Spain et al., 1950).

TABLE I

InCIDENCE of Myocardial Lesions in Poliomyelitis

Found AT POST-MORTEM EXAMINATION

\begin{tabular}{l|c|c}
\hline \multicolumn{1}{c|}{ Author } & Total examined & $\begin{array}{c}\text { Number showing myocardial } \\
\text { changes }\end{array}$ \\
\hline Saphir and Wile (1942) & 7 & 6 \\
Peale and Lucchesi (1943) & 9 & 7 \\
Dublin and Larson (1943) & 12 & 2 \\
Saphir (1945) & 17 & 40 \\
Gefter et al. (1947) & 6 & 16 \\
Dolgopol and Cragan (1948) & 92 & 14 \\
Ludden and Edwards (1949) & 35 & 14 \\
Spain et al. (1950) & 16 & \\
\hline
\end{tabular}


Macroscopic appearance of the heart. Saphir (1945) described the heart as flabby and soft. The muscle was commonly pinkish-grey in colour with a "boiled" appearance. In many specimens there was flattening of the papillary muscles and chordæ tendineæ. The weight of the heart is increased according to Ludden and Edwards (1949) although Spain et al. (1950) disagree. Dilatation of the ventricles, especially the right, is described by Gefter et al. (1947) and by Ludden and Edwards (1949). Endocardial and epicardial petechiæ are common and may resemble those seen in other acute illnesses complicated by anoxæmia.

Ludden and Edwards (1949) described specimens showing respectively a perforation of the posterior wall of the right atrium and an accompanying hæmopericardium; non-rheumatic verrucous endocarditis of the mitral valve; endarteritis of a patent ductus arteriosus; and obliterative pericarditis. They questioned whether the last two lesions could be attributed to the fatal poliomyelitis, but mitral verrucous endocarditis has been previously described by Luhan (1946).

Microscopic lesions in the myocardium. Later descriptions differ little from those recorded by Saphir and Wile in 1942. Damage to myocardial fibres varies from loss of striation with aggregation of nuclei, cloudiness, and thinning to discrete areas of focal necrosis. Peale and Lucchesi (1943) observed fragmentation of muscle bundles and nuclear pyknosis. Dolgopol and Cragan (1948) described foci in which the fibres have multiple nuclei; they could not say whether the nuclei were derived from the fibres themselves or from blood vessels.

Focal necrotic lesions were first described by Ludden and Edwards (1949). In one specimen there were scattered areas in the posterior wall of the left ventricle in which muscle fibres were replaced by large mononuclear cells in a lacework of connective tissue cells. Although no fibroblastic activity was seen, these areas are described as " healed." Similar areas of " healing " were seen by Baskin et al. (1950) and Boucek et al. (1949). Spain et al. (1950) describe fibroblasts, indicating repair, in two of their specimens, after an illness lasting 22 days.

Damage to the myocardial fibres was usually accompanied by an interstitial exudate consisting of focal collections of lymphocytes and polymorphonuclear cells. Polymorphs predominated in those areas where the muscle fibre damage was greatest. Occasionally the exudate was widespread throughout large areas of myocardium. Collections of cells were found chiefly in the wider bands of connective tissue between muscle fibres, and around the smaller blood vessels. Saphir (1945) and Dolgopol and Cragan (1948) remark that myocardial lesions are frequent where there are sub-epicardial and endocardial petechiæ, the most profuse lesions occurring in the left papillary muscles and ventricular septum. Saphir (1945) found unusual fibrinoid material in the media of the aorta.

Myocarditis is on the whole minor in extent and non-specific in character, similar to the lesions seen in other virus infections such as influenza and mumps. There is a gradation in damage from minimal focal areas of degeneration to patches of necrosis. Polymorphonuclear cells predominate in the earlier and more severe lesions, and later necrotic lesions may show signs of healing.

\section{Electrocardiographic Findings in Poliomyelitis}

The earliest electrocardiographic observations to be made in poliomyelitis were those of Peabody et al. (1912) who were studying the terminal arrhythmia. An illustration in their paper shows pronounced sinus arrhythmia which was attributed to vagal disturbance.

The first comprehensive report was by Gefter et al. (1947). The abnormalities described in this and subsequent papers are summarized in Table II, the most frequently observed changes being in T waves and S-T segments. Gefter et al. (1947) found abnormal records more frequently in severe forms of poliomyelitis but this has not been confirmed by others. Frischknecht and Zellweger (1950) suggested that transient $T$ wave changes early in the illness were caused by sympathetic disturbance, whereas those persisting for more than three weeks were due to myocarditis. Among unusual changes they mention the occurrence of auricular systoles on the fifth day of illness. After one year this patient had developed a typical Wolff-Parkinson-White syndrome. The first observations on the Q-T interval in poliomyelitis and its value as an indication of myocardial involvement were made by Joos and Yu (1950). 
TABLE II

Electrocardiographic Abnormalities in Poliomyelitis

\begin{tabular}{|c|c|c|c|c|c|c|c|}
\hline Author & $\begin{array}{l}\text { No. in } \\
\text { series }\end{array}$ & $\begin{array}{l}\text { Excessive } \\
\text { tachycardia }\end{array}$ & $P$ wave & $\begin{array}{l}\mathbf{P}-\mathbf{R} \\
\text { interval }\end{array}$ & $\begin{array}{c}\text { QRS } \\
\text { complex }\end{array}$ & $\begin{array}{c}\text { S-T } \\
\text { segment } \\
\text { deviation }\end{array}$ & $T$ wave \\
\hline $\begin{array}{l}\text { Gefter } \text { et al. } \\
\text { (1947) }\end{array}$ & $\begin{array}{c}226 \\
\text { (32 abnormal) }\end{array}$ & 9 & $\begin{array}{l}\text { High and } \\
\text { peaked in } 6\end{array}$ & $\begin{array}{l}\text { Prolonged } \\
\text { in } 7\end{array}$ & $\underset{1}{\text { Slurred }}$ & 5 & 8 \\
\hline $\begin{array}{l}\text { Boucek et al. } \\
\text { (1949) }\end{array}$ & 1 & - & - & - & - & $\begin{array}{l}\text { Elevation } \\
\text { in lead } 1\end{array}$ & Diphasic \\
\hline $\begin{array}{l}\text { Bradford and } \\
\text { Anderson (1950) }\end{array}$ & $\begin{array}{c}155 \\
\text { (20 abnormal) }\end{array}$ & 12 & - & 2 & - & - & 16 \\
\hline $\begin{array}{l}\text { Firpi et al. } \\
\text { (1949) }\end{array}$ & $\begin{array}{c}44 \\
\text { (10 abnormal) }\end{array}$ & - & - & 1 & - & 8 & 1 \\
\hline $\begin{array}{l}\text { Joos and } Y u \\
(1950)\end{array}$ & $\begin{array}{c}23 \\
\text { (7 abnormal) }\end{array}$ & 4 & - & 1 & - & $\begin{array}{l}\text { Prolonged } \\
\text { Q-Tc in } 5\end{array}$ & - \\
\hline $\begin{array}{l}\text { Frischknecht and } \\
\text { Zellweger } \\
(1950)\end{array}$ & $\begin{array}{c}52 \\
\text { (21 abnormal) }\end{array}$ & - & $\begin{array}{l}\text { Negative } \\
\text { in } 1\end{array}$ & 1 & $\begin{array}{l}\text { W-P-W } \\
\text { syndrome } \\
\text { in } 1\end{array}$ & - & 18 \\
\hline
\end{tabular}

\section{Material AND Results}

Electrocardiograms were taken in 55 children out of a total of 102 who were admitted to the Children's Hospital, Birmingham, with poliomyelitis during the summer of 1950 . Chest leads were taken where indicated but this was technically impossible when patients were in the respirator. In the majority, weekly readings were taken, but in 13 only a single tracing was obtained. Unfortunately no records were obtained in children who later died, as all required immediate treatment in the respirator. It was thus impossible to correlate the electrocardiographic picture and the histological appearance of the heart. Several records were, however, made in 5 other children who required a respirator and survived.

The clinical manifestations were classified as follows: non-paralytic 15; spinal paralytic 28; bulbar 4; bulbospinal 4; encephalitic 2; midbrain syndrome (tremor, ataxia, opsoclonia) 2 . The youngest patient was an infant twelve days old whose mother died of fulminating polioencephalitis three days after the infant's birth. The infant had paralysis of all four limbs, but there was no electrocardiographic abnormality.

Abnormal records were obtained from 13 children. No disturbances of rhythm were seen, but 12 children had tachycardia exceeding 150 beats a minute when the first recording was taken. This was not thought to be excessive in view of a fever frequently as high as $103^{\circ}$ or $104^{\circ} \mathrm{F}$. The results are summarized in Table III.

$Q$ waves. Deep Q waves were present in leads II and III in Case 1 on the 13th day. Q II was no longer present and Q III was smaller on the 158th day (Fig. 1). Persistent deep Q III waves were observed in Case 2, in which there were associated S-T segment changes. In 6 other children Q III was the only abnormality; 2 were 16 months old, 3 were 2 years old, one was 4 years old. Their significance is very doubtful; such waves are common in normal children.

$S-T$ segment and $T$ waves. Cases $3,4,5$, and 6 showed transient $T$ changes with associated abnormal deviation of S-T segments. The changes occurred in the first three weeks of the illness after which both $T$ waves and S-T segments were normal. In Case 6 the blood pressure was $125 / 80$ on the tenth day, falling to $90 / 50$ on the twentieth day (Fig. 2). In Case 7, who had a most severe attack of poliomyelitis, S-T and T changes persisted for over two months from the onset. It was thought that myocardial damage had been severe (Fig. 3). Cases 8 and 9 had transient 
TABLE III

Summary of Abnormal Electrocardiographic Findings in Poliomyelitis 55 Patients Examined: Abnormal Records in 13 Children

\begin{tabular}{|c|c|c|c|c|c|c|c|c|c|c|}
\hline No. & $\operatorname{Sex}$ & Age & $\begin{array}{l}\text { Clinical } \\
\text { Type }\end{array}$ & Paralysis & $\mathbf{Q}$ & $\mathbf{S}-\mathbf{T}$ & $\mathbf{T}$ & $\mathbf{P}-\mathbf{R}$ & Q-Tc & Notes \\
\hline 1 & $\mathbf{M}$ & $6 \cdot 4$ & S.P. & R. lower limb. & + & & & + & & Transient weakness $R$. ant. tibials \\
\hline 2 & $\mathbf{M}$ & $2 \cdot 4$ & S.P. & L. lower limb. & + & + & & + & & Residual weakness L. ant. tibials \\
\hline 3 & $\mathbf{F}$ & $1 \cdot 2$ & S.P. & $\begin{array}{l}\text { R. upper and } \\
\text { lower limbs and } \\
\text { intercostals }\end{array}$ & & + & + & & + & $\begin{array}{l}\text { Transient paralyses. Complete re- } \\
\text { covery }\end{array}$ \\
\hline 4 & $\mathbf{M}$ & $4 \cdot 9$ & S.P. & $\begin{array}{l}\text { All four limbs } \\
\text { and intercostals }\end{array}$ & & + & + & & & $\begin{array}{l}\text { Respirator } 3 \text { days. Gross residual } \\
\text { weakness all four limbs }\end{array}$ \\
\hline 5 & $\mathbf{F}$ & $3 \cdot 9$ & N.P. & - & & + & + & & & No paralysis \\
\hline 6 & $\mathbf{F}$ & $10 \cdot 8$ & B.S. & $\begin{array}{l}9 \text { and } 10 \text { C.N. } \\
\mathbf{R} \text { upper limb } \\
\text { and both lower } \\
\text { limbs }\end{array}$ & & + & + & & & $\begin{array}{l}\text { Recovery bulbar palsy. Residual weak- } \\
\text { ness both lower limbs }\end{array}$ \\
\hline 7 & $\mathbf{F}$ & $9 \cdot 3$ & S.P. & $\begin{array}{l}\text { All } 4 \text { limbs and } \\
\text { intercostals }\end{array}$ & & + & + & & & $\begin{array}{l}\text { Respirator } 6 \text { weeks. Gross residual } \\
\text { weakness all four limbs }\end{array}$ \\
\hline 8 & $\mathbf{F}$ & $2 \cdot 9$ & B.S. & $\begin{array}{l}7,9,10 . \text { C.N. } \\
\text { All four limbs } \\
\text { and intercostals }\end{array}$ & & & + & & + & $\begin{array}{l}\text { Respirator } 7 \text { weeks. Gross residual } \\
\text { weakness all four limbs and intercostals }\end{array}$ \\
\hline 9 & $\mathbf{F}$ & $13 \cdot 3$ & B.S. & $\begin{array}{l}7,9,10 \text { C.N. } \\
\text { R. upper and } \\
\text { R. lower limb }\end{array}$ & & & + & & & $\begin{array}{l}\text { Recovery bulbar palsies. Weakness } R \text {. } \\
\text { triceps and ant. tibials }\end{array}$ \\
\hline 10 & $\mathbf{M}$ & $2 \cdot 2$ & S.P. & $\begin{array}{l}\text { R. upper limb } \\
\text { and intercostals }\end{array}$ & & & & + & + & $\begin{array}{l}\text { Transient intercostal weakness. Resi- } \\
\text { dual weakness } R \text {. triceps, shoulder } \\
\text { girdle }\end{array}$ \\
\hline 11 & $\mathbf{F}$ & $5 \cdot 1$ & B.S. & $\begin{array}{l}\text { 7. Both upper } \\
\text { limbs and inter- } \\
\text { costals }\end{array}$ & & & & + & + & $\begin{array}{l}\text { Respirator } 3 \text { weeks. Residual weak- } \\
\text { ness upper limbs }\end{array}$ \\
\hline 12 & $\mathbf{F}$ & $6 \cdot 2$ & S.P. & Both lower limbs & & & & & + & $\begin{array}{l}\text { Residual weakness left quadriceps, ant. } \\
\text { tibials }\end{array}$ \\
\hline 13 & $\mathbf{M}$ & $1 \cdot 5$ & S.P. & Both lower limbs & & & & & + & Residual paralysis both lower limbs \\
\hline
\end{tabular}

$$
\text { N.P. }=\text { non-paralytic } \quad \text { S.P. }=\text { spinal paralytic } \quad \text { B.S. }=\text { bulbospinal } \quad \text { C.N. }=\text { cranial nerves }
$$

flattening of $T$ waves early in the illness, returning rapidly to normal. In Case 8, a blood pressure of $134 / 100$ on the tenth day had fallen to $95 / 70$ on the fifty-fifth day.

$P-R$ interval. The $P-R$ interval was prolonged in 4 children, using the standards for age and heart rate recommended by Ashman and Hull (1941). In two, there was also prolongation of the Q-Tc interval.

Q-T interval. Following the method of Abrahams (1949), the Q-T interval was measured in each record taken. Corrected values were calculated according to Bazett's formula (1920). Taran and Szilagyi (1947) take 0.405 seconds as the upper limit of normal for the corrected Q-T interval or Q-Tc in childhood. Abrahams (1949) recommends a higher value of 0.422 seconds, which has been adopted as the upper limit of normality in this series. The duration of electrical systole as measured by Q-Tc was prolonged in 6 patients. 
Case 1

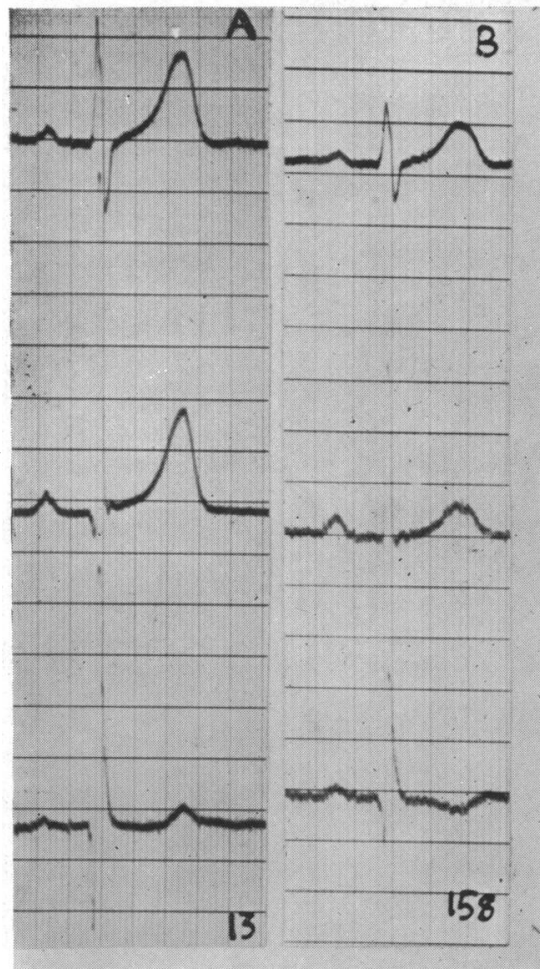

Case 3

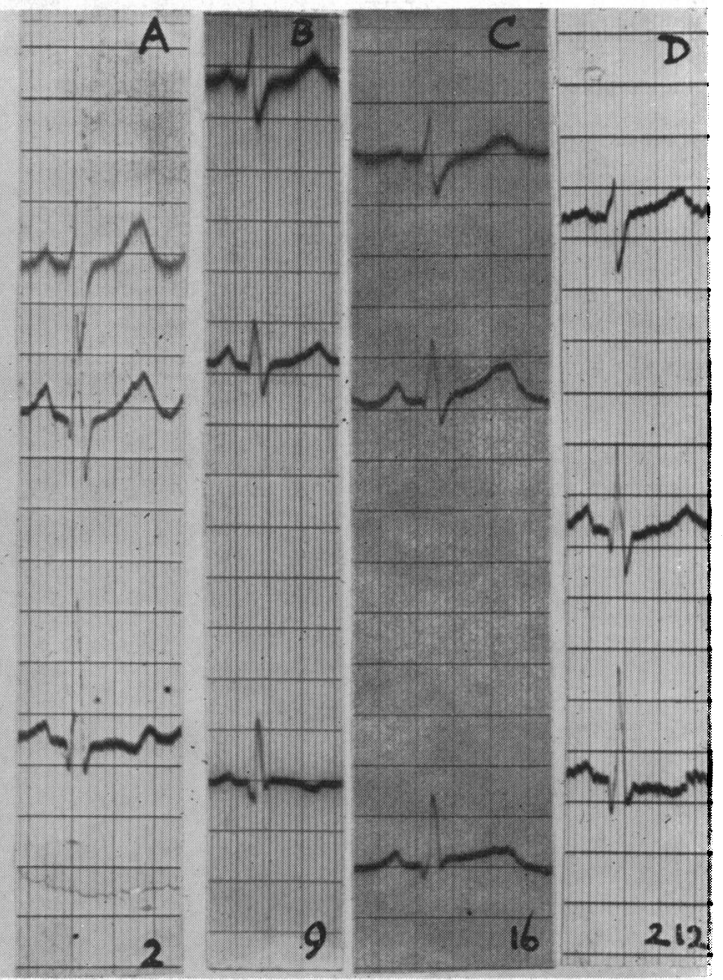

Fig. 1.-Case 1. (A) 13th day, Q2 and deep Q3; P-R, $0 \cdot 18$ sec. (B) 158th day, Q3 smaller; P-R, $0.16 \mathrm{sec}$. Case 3. (A) 2nd day, depression, S-T3; Biphasic T3; Q-Tc, 0.416 sec. (B) 9th day, S-T3 normal; T3 inverted; Q-Tc, 0.454 sec. (C) 16th day, S-T3 normal; T3 upright; Q-Tc, 0.432 sec. (D) 212 th day, depression S-T3; Q-Tc, $0.462 \mathrm{sec}$.

Case 3. Q-Tc was within normal limits $(0.416 \mathrm{sec}$.) on the second day of illness. It rose on the ninth day to $0.454 \mathrm{sec}$. and was 0.432 on the sixteenth day. A final reading on 212 th day was $0.462 \mathrm{sec}$. An apical systolic murmur was audible at the time Q-Tc was first known to be prolonged (Fig. 1).

Case 8. There was flattening of $\mathrm{T}$ waves early in the illness. On the $71 \mathrm{st}$ day $\mathrm{Q}-\mathrm{Tc}$ was $0.432 \mathrm{sec}$. (Fig. 5).

Case 10. On the ninth day of illness $\mathrm{P}-\mathrm{R}, 0.13 \mathrm{sec}$; $\mathrm{Q}-\mathrm{Tc}, 0.377 \mathrm{sec}$. By the $33 \mathrm{rd}$ day, $\mathrm{P}-\mathrm{R}, \mathbf{0} \cdot 16 \mathrm{sec}$; $\mathrm{Q}-\mathrm{Tc}, 0.430 \mathrm{sec}$. Intercostal weakness present from 8 th to 29 th day. On 228 th day, $\mathrm{P}-\mathrm{R}, 0.13 \mathrm{sec}$; Q-Tc, 0.345 sec.

Case 11. On the $21 \mathrm{st}$ day of illness, P-R, $0.16 \mathrm{sec}$; Q-Tc, $0.444 \mathrm{sec}$; By 42nd day, P-R, $0.17 \mathrm{sec}$; Q-Tc, $0.453 \mathrm{sec}$. Intercostal weakness present from 4th to 21 st day (Fig. 4).

Case 12. Q-Tc was $0.449 \mathrm{sec}$. on fourteenth day. Further readings of Q-Tc were $0.466 \mathrm{sec}$. and 0.449 sec. on 35th and 108th days. No respiratory weakness (Fig. 4).

Case 13. Q-Tc was $0.435 \mathrm{sec}$. on the twelfth day. No respiratory weakness.

In 4 patients there was respiratory muscle weakness. In Cases 3, 8, and 10, Q-Tc was normal at the onset of respiratory weakness. The duration of respiratory weakness before Q-Tc was prolonged was 7 days in Case 3, 65 days in Case 8, and 25 days in Case 10. In Case 10, Q-Tc had returned to normal on 228th day of illness. In Case 11, the data are incomplete, but prolongation was present 17 days after the onset of respiratory weakness and remained so 21 days later.

\section{Discussion}

The preponderance of histological cardiac lesions in children is perhaps simply a reflection of the higher incidence of the disease itself in younger subjects. The youngest on record is that of 
Baskin et al. (1950) who found severe lesions in a five-day-old infant. Ludden and Edwards (1949), whose series included many adults, thought that the cardiac damage was most severe in older patients, although this was not confirmed by Spain et al. (1950). Ludden and Edwards found that

\section{Case 4}

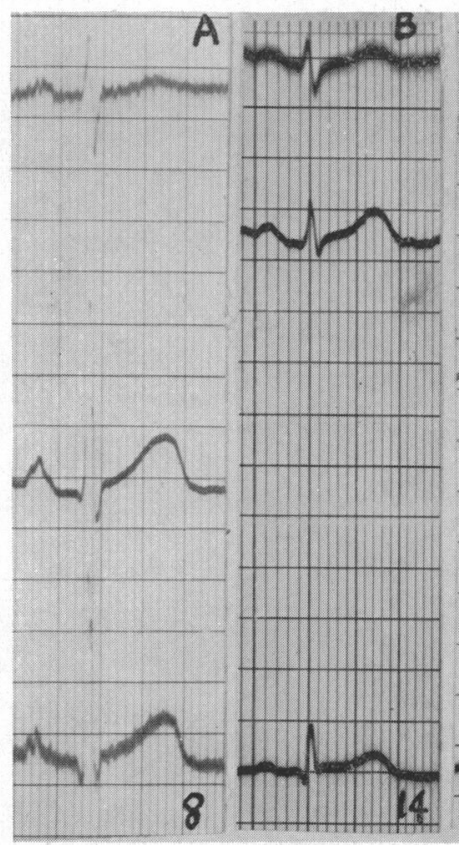

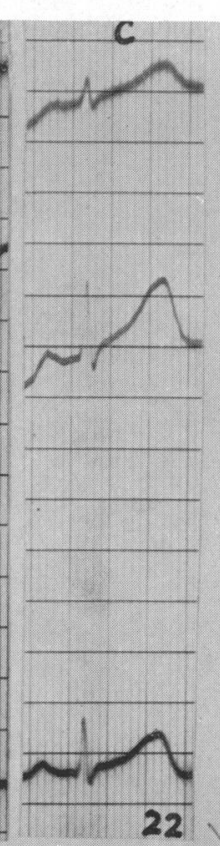

Case 6

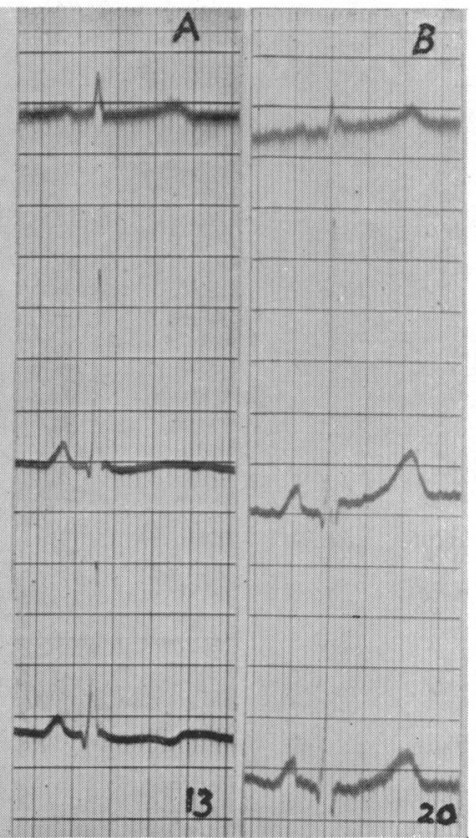

FIG. 2.-Case 4. (A) 8th day, elevation S-T2 and 3; T2 and T3 domed. (B) 14th day, elevation of S-T2 and 3. (C) 22nd day, T3 increased in amplitude. Case 6. (A) 13 th day, depression of ST-2 and 3; flat T waves. (B) 20th day, S-T2 and 3 normal; $T$ waves normal.

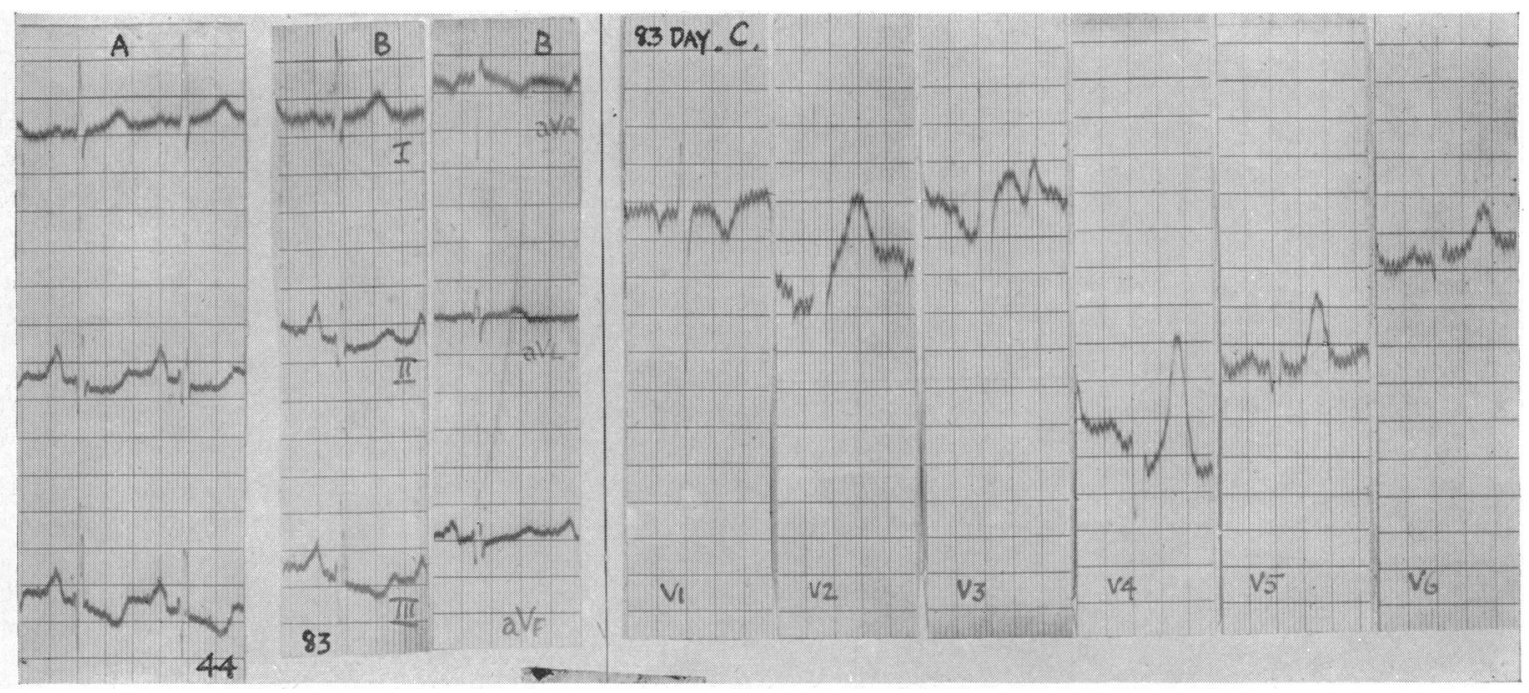

Fig. 3.-Case 7. (A) 44th day, depression S-T2 and 3; inverted T2 and 3. (B) 83rd day, T2 normal; T3 inverted. (C) 83rd day, S-T elevated in V2 and 3; bifid $\mathrm{T}$ in V3; tall $\mathrm{T}$ in V4. 

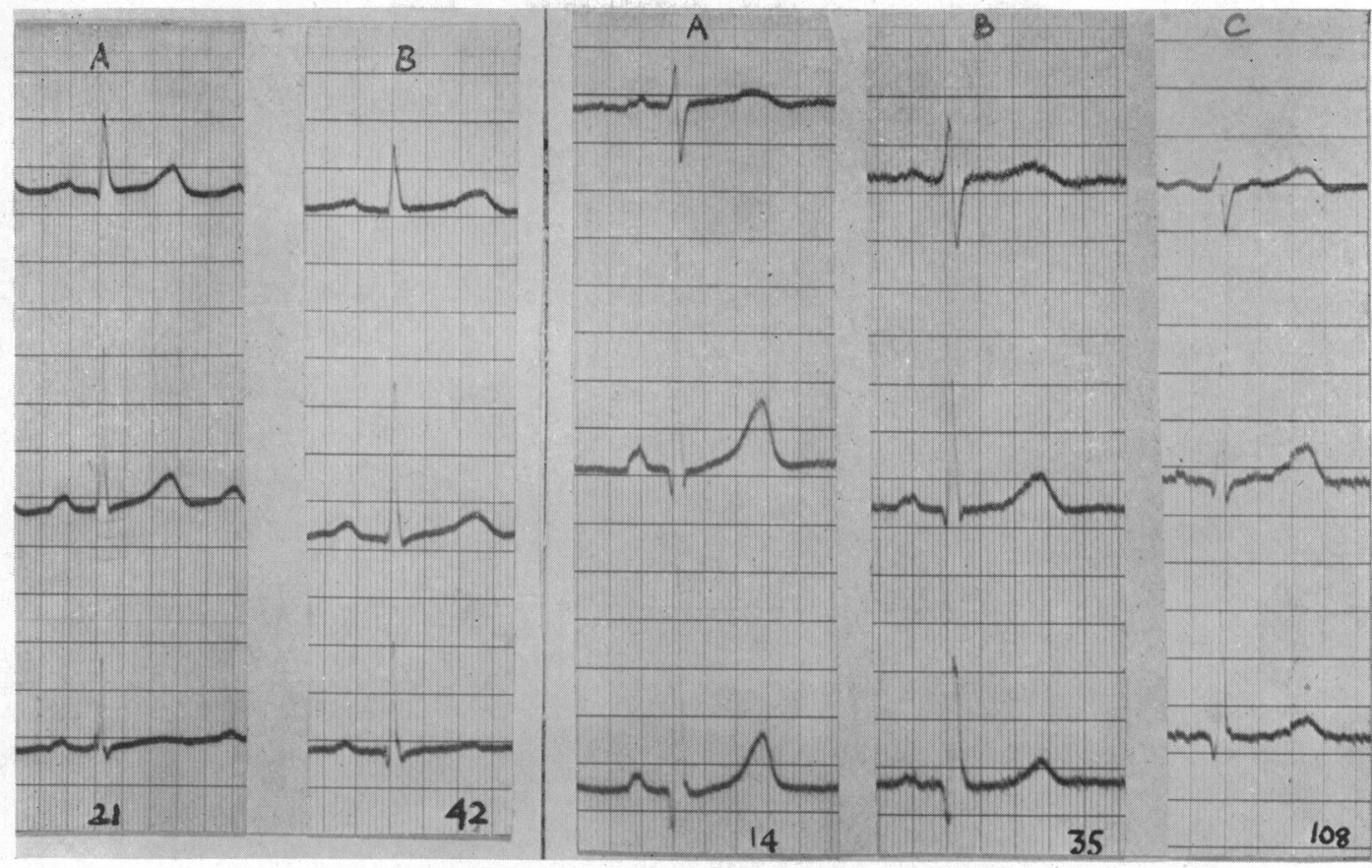

Fig. 4.-Case 11. (A) 21st day, P-R, 0.16 sec.; Q-Tc, 0.444 sec. (B) 42nd day, P-R, 0.18 sec.; Q-Tc, $0.453 \mathrm{sec}$. Case 12. (A) 14th day, P-R, 0.14 sec.; Q-Tc, $0.449 \mathrm{sec}$. (B) 35th day, P-R, 0.14 sec.; Q-Tc, $0.466 \mathrm{sec}$. (C) 108 th day, P-R, 0.13 sec.; Q-Tc, $0.449 \mathrm{sec}$.

males were more often affected than females, but this too is probably a reflection of the longrecognized higher incidence of poliomyelitis in males. In the majority death took place early in the disease in those showing cardiac damage. 12 of 16 cases reported by Dolgopol and Cragan (1948) died in the first five days of the illness. Thirteen of Ludden and Edward's series (1949) died in less than 11 days from the onset.

In no series has it been possible to correlate the clinical type of disease with the presence of histological myocarditis, which may apparently follow any severe form. Saphir and Wile (1942) suspected myocarditis if the patient became suddenly worse, or if he had either tachycardia or bradycardia together with cyanosis. On the other hand Ludden and Edwards (1949) recognized that tachycardia, irregularity of the pulse, dyspnoea, and cyanosis are common terminal findings in poliomyelitis, whether or not myocarditis is present. In three of their patients a basal systolic murmur was audible, and one of them later proved to have a moderately severe myocarditis. It is difficult to say whether myocarditis is responsible for sudden death in poliomyelitis. Sudden death took place in six of Ludden and Edward's series, three of whom had myocarditis, but in these bulbar damage was severe and might have been responsible.

Pathogenesis of Myocarditis in Poliomyelitis. Before considering the possible role played by the poliomyelitis virus, other alternative ætiological factors have to be mentioned. Myocarditis is a well-recognized histological feature in fatal bronchopneumonia (Stone, 1922). Bronchopneumonia is a frequent post-mortem finding in poliomyelitis and by some has been held responsible for myocardial changes. Myocarditis may, however, occur in the absence of pneumonia, and pneumonia without myocardial changes (Saphir and Wile, 1942). Six of Dolgopol and Cragan's patients (1948) died so early that bacterial invasion of the lungs was probably too slight to cause cardiac damage. An opposing view is taken by Bell (1949) who, quoting the work of Clawson considers that respiratory infection is the probable cause of myocarditis.

French and Weller (1942) showed that sulphonamide drugs may cause myocardial damage in both the experimental animal and in man, but myocardial changes in poliomyelitis were recognized before the 
introduction of therapeutic sulphonamides. It is consequently unlikely that these drugs play any part in producing lesions in poliomyelitis.

The patient described by Clark (1938) had been given horse serum as a therapeutic measure early in the disease. Signs of serum sensitivity appeared before death. Diffuse interstitial myocarditis was revealed at necropsy, and was attributed to some form of hypersensitivity reaction. Although sera have been abandoned in the treatment of poliomyelitis, they have to be considered as possibly responsible for myocardial damage. Saphir (1945) whose 10 patients with myocarditis had been given serum does not believe that it was responsible for the cardiac lesion. Similarly, Dolgopol and Cragan (1948) and Ludden and Edwards (1949) conclude that horse serum could not be responsible for a hypersensitivity reaction causing myocarditis when it had been given for so short a time.

Poliomyelitis virus was isolated for the first time from the heart of a fatal case in 1949 (quoted by Jungeblut, 1950). The pathway by which poliomyelitis virus reaches the heart is not known. The evidence that virus may be present in the blood is scanty. Ward et al. (1946), isolated virus from the blood of only one out of 111 patients with poliomyelitis, but the possibility of a viræmic phase is suggested by the presence of inflammatory lesions in the pectoral muscles and diaphragm (Hassin, 1943), and the isolation of poliomyelitis virus from paralysed muscle in the acute stage of the illness (Jungeblut and Stevens, 1950).

Pearce (1950) has reviewed the mechanisms involved in the production of virus myocarditis in the experimental animal. He showed that in the rabbit myocarditis could be induced with several different viruses, not previously thought to have any cardiotropic activity, provided there was anoxæmia of the cardiac muscle. The results of such experiments must be applied to man with reservation, but it may be that a similar mechanism is involved in the pathogenesis of the human disease.

The relationship of electrocardiographic changes to histological damage is still imperfectly understood. Among the few reported cases is that of Boucek et al. (1949) in which S-T and T changes were associated with concentrated damage in the left ventricle. Bradford and Anderson (1950) found abnormal records in 4 of 5 fatal cases, 3 of whom had myocarditis. Frischknecht and Zellweger (1950) found no histological abnormality in the heart in 2 patients who had shown abnormal $\mathrm{T}$ waves on the fifth day of illness.

Present Series. The pattern of electrocardiographic abnormalities corresponds to those reported in previous series. Abnormal records were obtained in 13 of 55 children examined, the most frequently occurring abnormalities being in the $S-T$ segments and $T$ waves. The occurrence of 


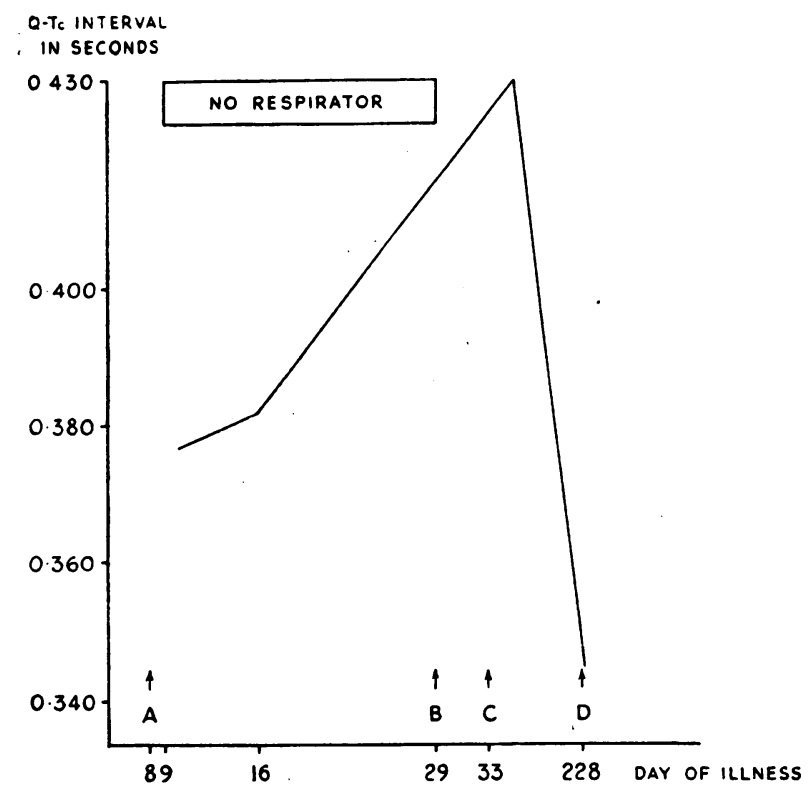

FIG. 6.-Case 10. Showing increase in Q-Tc interval related to respiratory muscle paralysis. Q-Tc returned to normal on 228 th day of illness. (A) Day 8 , onset of intercostal weakness. (B) Day 29, recovery from intercostal weakness. (C) Day 33, prolonged Q-Tc. (D) Day 228, normal Q-Tc.

respiratory muscle paralysis in 4 of 6 children in whom there was prolongation of the Q-Tc interval has been mentioned previously. Cardiographic abnormalities occurred more often in those with respiratory muscle paralysis than in those not so affected. Of 7 with respiratory paralysis, 6 had abnormal cardiograms, while of 48 without respiratory paralysis, only 7 showed abnormal records. These results may be compared with those of Joos and Yu (1950), in which three children had intercostal weakness, the Q-Tc interval being prolonged in two; in 20 without respiratory paralysis Q-Tc was prolonged in three.

The incidence of electrocardiographic abnormalities in the different clinical groups of poliomyelitis shows the highest incidence to be in the bulbospinal group, the lowest in the non-paralytic. All four bulbospinal patients had abnormal records. Eight of 25 records in spinal paralytic cases were abnormal. Only one of 15 non-paralytic cases was abnormal. No abnormal records were obtained in the bulbar or encephalitic patients examined, nor in two with an unusual midbrain syndrome. The age of the patient did not appear to be related to the abnormalities in the cardiogram. Prolongation of the Q-Tc interval was not, however, seen in any child over six years of age.

The clinical evidence of myocardial disease was small. Tachycardia with cyanosis and dyspnœa are usual findings in respiratory paralysis and could not be attributed with any confidence to cardiac disease. In no case was there enlargement of the heart. In one there was a transient apical systolic murmur at a time when the Q-Tc interval was prolonged (Case 3). This may have indicated true myocardial involvement. There was temporary elevation of the blood pressure in Cases 6 and 8 , both of whom had bulbospinal involvement. The association of cardiographic changes with respiratory muscle paralysis suggests that in some they may be related to anoxæmia. The effect of oxygenation on the electrocardiogram of patients in the respirator may give a more satisfactory answer to this question. 


\section{SUMMARY}

Electrocardiograms were taken in 55 children with poliomyelitis. Abnormalities were found in 13. They were non-specific in character and included $Q$ wave abnormalities in $2, S-T$ segment and $T$ wave changes in 5 , $T$ wave changes in 2 , prolongation of $P-R$ interval in 4 , and prolongation of $\mathrm{Q}-\mathrm{Tc}$ in 6.

The lowest incidence of changes was in the non-paralytic group, the highest in the bulbospinal. The relationship of electrocardiographic changes to respiratory muscle paralysis is discussed.

My thanks are due to the Physicians to the Children's Hospital, Birmingham, for permission to investigate their patients. In particular I have to thank Dir. Clifford Parsons and Professor J. M. Smellie for their advice during the preparation of this paper, and Miss J. Wright who took several of the recordings.

\section{REFERENCES}

Abrahams, D. G. (1949). Brit. Heart J., 11, 342.

Abramson, H. L. (1918). Arch. intern. Med., 22, 312.

Ashman, R., and Hull, E. (1941). Essentials of Electrocardiography. New York.

Baskin, J. L., Soule, E. H., and Mills, S. D. (1950). Amer. J. Dis. Child., 80, 10.

Bazett, H. C. (1920). Heart, 7, 353.

Boucek, R. J., Bailey, A. A., Burchell, H. B., Edwards, J. E. (1949). Proc. Mayo. Clin., $24,495$.

Bradford, H. A., and Anderson, L. L. (1950). Ann. intern. Med., 32, 270.

Clark, E. (1938). J. Amer. med. Ass., 110, 1098.

Clawson, B. J., quoted by E. T. Bell (1949). Poliomyelitis. 1st International conference, Philadelphia.

Cowie, D. M., Parsons, J. P., Lowenberg, K. (1934). Ann. intern. Med., 8, 521.

Dolgopol, V. B., and Cragan, M. D. (1948). Arch. Path., 46, 202.

Dublin, W. B., and Larson, C. P. (1943). Amer. J. Clin. Path., 13, 15.

Firpi, M. A., Murphy, F. J., Walsh, B. J., Anderson, W. S. (1949). Clin. Proc. Child. Hosp. Washington D.C., 5, 239. French, A. J., and Weller, C. V. (1942). Amer. J. Path., 18, 109.

Frischknecht, W., and Zellweger, H. (1950). Helv. paed. Acta., 5, 448.

Gefter, W. I., Leaman, W. G., Lucchesi, P. R., Maher, I. E., and Dworin, M. (1947). Amer. Heart. J., 33, 228.

Harbitz, F., and Scheel, O. (1907). Pathologisch-anatomische Untersuchungen über akute Poliomyelitis-Christiania.

Hassin, G. B. (1943). J. Neuropath. Exp. neurol., 2, 293.

Joos, H. A., and Yu, P. N. G. (1950). Amer. J. Dis. Child., 80, 22.

Jungeblut, C. W. (1950). J. Pediat., 37, 109.

, and Stevens, M. A. (1950). Amer. J. Clin. Path., 20, 701.

Ludden, T. E., and Edwards, J. E. (1949). Amer. J. Path., 25, 357.

Luhan, J. A. (1946). Arch. Path., 42, 245.

Peabody, F. W., Draper, G., and Dochez, A. R. (1912). A Clinical Study of Acute Poliomyelitis. Monographs of Rockefeller Institute for Medical Research No. 4.

Peale, A. R., and Lucchesi, P. F. (1943). Amer. J. Dis. Child., 65, 733.

Pearce, J. M. (1950). Pathogenesis and Pathology of Viral Diseases. Edited J. G. Kidd. New York.

Robertson, H. E., and Chesley, A. J. (1910). Arch. intern. Med., 6, 233.

Sabin, A. B., and Aring, C. D. (1941). Amer. J. Path., 17, 469.

Saphir, O. (1945). Amer. J. Path., 21, 99. , and Wile, S. A. (1942). Amer. J. Med. Sci., 203, 781.

Spain, D. M., Bradess, V. A., and Parsonnet, V. (1950). Amer. Heart J., 40, 336.

Stone, W. J. (1922). Amer. J. med. Sci., 163, 659.

Taran, L. M., and Szilagyi, N. (1947). Amer. Heart. J., 33, 14.

Ward, R., Horstmann, D. M., and Melnick, J. L. (1946). J. Clin. Invest., 25, 284.

Wickman, I. (1907). Acute Poliomyelitis. Translation-Nervous and Mental Diseases, Monograph Series. No. 16. 1913 . 